\title{
Results of a Producer Survey Regarding Crossbreeding on US Dairy Farms
}

\author{
K. A. Weigel* and K. A. Barlass $†$ \\ ${ }^{*}$ Department of Dairy Science, University of Wisconsin, Madison 53706 and \\ †American Jersey Cattle Association, Reynoldsburg, $\mathrm{OH} 43068$
}

\begin{abstract}
Comprehensive surveys were sent to 528 US dairy producers who are currently practicing crossbreeding in their herds. Fifty usable surveys were returned, and the resulting data included qualitative responses regarding facilities, milk recording plans, milk pricing, crossbreeding goals, breed selection, advantages, disadvantages, and future plans. Quantitative variables included producer scores on a 1 to 5 scale for questions regarding ability to fit into the free stalls and milking parlor, milk volume, component percentages, involuntary culling rate, conception rate, calving difficulty, calf mortality, and prices for breeding stock, cull cows, market steers, and bull calves. The most common first generation crosses involved Jersey and Brown Swiss bulls mated to Holstein cows, and backcrosses to one of these parental breeds were most common in the next generation. Producers who responded to this survey desired, and indicated that they achieved, improvements in fertility, calving ease, longevity, and component percentages through crossbreeding. Respondents indicated that crosses involving the Jersey and Brown Swiss breeds had a clear advantage in longevity relative to purebred Holsteins, and conception rates for crosses of Jersey or Brown Swiss sires on Holstein cows were similar to the (high) conception rates typically achieved in purebred Jersey matings. Respondents also indicated that milk composition was improved in the crossbred cattle, but producers cited some difficulties in marketing crossbred breeding stock and bull calves, and noted that the lack of uniformity within the milking herd created management challenges. Based on results of this survey, it appears that crossbreeding can improve the health, fertility, longevity, and profitability of commercial dairy cattle. However, further research is needed regarding specific heterosis estimates for functional traits in crosses involving each of the major dairy breeds, and improvements are needed in systems
\end{abstract}

Received May 23, 2002.

Accepted June 16, 2003.

Corresponding author: K. A. Weigel; e-mail: weigel@calshp.cals. wisc.edu. for recording the ancestry and breed composition of crossbred animals.

(Key words: crossbreeding, dairy cattle, survey)

\section{INTRODUCTION}

Dairy producers have become increasingly interested in crossbreeding in recent years for three reasons. First, changes in milk pricing have rewarded herds with high fat and protein percentages, and this has enhanced the ability of other breeds and breed crosses to compete with Holsteins on an economic basis. Second, some producers have begun experimenting with crossbreeding because of concerns regarding female fertility, calving ease, health, and survival in the Holstein breed. Third, inbreeding levels are increasing rapidly in all of the major dairy breeds, and crossbreeding may be an effective option for reducing the impact of inbreeding depression on commercial dairy farms.

Crossbreeding is used widely in genetic improvement programs for many plant and livestock species, but crossbreeding has not been accepted in most dairy cattle populations, presumably because of the advantage of Holstein cattle in milk volume and the strong historical influence of purebred breeders and breed associations. Swan and Kinghorn (1992), among others, have provided theoretical arguments to support crossbreeding in dairy cattle, and VanRaden and Sanders (2001) noted that the expected profitability of $\mathrm{F}_{1}$ Holstein $\times$ Jersey cows or $\mathrm{F}_{1}$ Holstein $\times$ Brown Swiss cows can exceed that of pure Holstein cows in markets that place a substantial premium on fat and protein percentages. McAllister (2002) offered a comprehensive review of the current status of crossbreeding in US dairy cattle. He summarized several important crossbreeding trials that were conducted in North America during the past half-century. The most recent, a Canadian study by McAllister et al. (1994), reported more than 20\% heterosis for lifetime profitability in crosses involving the Holstein and Ayrshire breeds. Maternal traits of the Ayrshire breed were favored, and some groups of crossbred cattle were equivalent to pure Holstein controls in lifetime net profit. In an earlier study, Touchberry et al. (1992) evaluated a cross between the Holstein and 
Guernsey breeds. Heterosis was observed in net profit per lactation, but the crossbred animals were still inferior to pure Holsteins.

Crossbreeding is popular in New Zealand, unlike most other leading dairy countries, and several studies have investigated the role of Holstein $\times$ Jersey crossbred cattle in their pastoral production system. AhlbornBreier and Hohenboken (1992) reported heterosis estimates of $6 \%$ for fat yield and $7 \%$ for protein yield in Holstein and Jersey crosses and noted that $F_{1}$ animals were superior to pure Holsteins for fat yield. More recently, Lopez-Villalobos et al. (2000) developed an economic model for evaluating the suitability of pure line breeding vs. rotational crossbreeding systems in New Zealand, and the Holstein, Jersey, and Ayrshire breeds were considered. Net income per hectare was maximized in a two-breed rotational cross involving Holstein and Jersey cattle, followed closely by a three-breed rotational cross involving Holstein, Jersey, and Ayrshire cattle.

The objective of this study was to conduct and summarize a comprehensive survey that would document the experiences of US dairy producers that are already using crossbreeding as a tool for genetic improvement of their herds, such that other producers can use this information when considering implementation of a crossbreeding program, and such that scientists can identify specific traits and breed crosses that deserve more detailed attention in future research projects.

\section{MATERIALS AND METHODS}

Dairy producers who were currently crossbreeding were identified using several sources, including: 1) presence of crossbred cows (breed of sire $\neq$ breed of dam) in the DHI milk recording system; 2) presence of crossbred matings (breed of service sire $\neq$ breed of cow) in the national bull fertility database; 3 ) registration of crossbred calves in a breed association "grading up" program; 4) referrals by AI technicians and semen salesmen, and 5) referrals by county extension agents and state extension specialists. An eight-page survey was developed in which these producers were asked to provide detailed information about their experiences with crossbreeding. Qualitative data included statements regarding their motivation for crossbreeding, reasons for choosing or avoiding certain breeds, current sire selection criteria, main advantages and disadvantages of crossbreeding in their herds, and future plans for their herds' breeding programs. In addition, data regarding their milk payment system, housing facilities, milking facilities, participation in DHI milk recording programs, and use of AI or natural service bulls were gathered. Quantitative data included producer-assigned scores on a 1 to
5 scale for each breed or breed cross regarding ability to fit into the freestalls and milking parlor, milk volume, fat and protein percentages, involuntary culling rate, conception rate, calving difficulty, calf mortality, and sale prices for breeding stock, cull cows, market steers, and bull calves. In each case, producers were asked to score animals of each pure breed or breed cross relative to the average of all other cows on their farms. Means and standard errors of the producers' responses were calculated for all breeds and breed crosses in which at least five farms were represented.

\section{RESULTS AND DISCUSSION}

Surveys were mailed to 528 dairy producers throughout the United States, and 50 completed surveys were returned (response rate $=9.5 \%$ ). Respondents were from the following states: Arizona (1), California (1), Connecticut (1), Iowa (3), Indiana (3), Kansas (2), Maryland (1), Maine (1), Minnesota (7), Missouri (2), North Carolina (1), Nebraska (2), New Hampshire (1), New York (7), Oklahoma (1), Oregon (2), Pennsylvania (1), South Carolina (2), South Dakota (1), Texas (3), Vermont (1), and Wisconsin (6).

Twenty-three participants received significant premiums for milk with high fat percentage, and 22 received significant premiums for protein percentage. Eighteen and 15 respondents received slight premiums for fat and protein percentage, respectively, whereas four and seven, respectively, received no premiums. Types of milking systems on these farms included: pit parlor (38 herds), stall barn with pipeline (8), and flat parlor (3). Primary types of housing for the milking herd included: confinement with free stalls (18 herds), confinement with loose housing (7), management-intensive rotational grazing (10), confinement with tie stalls (3), and a combination of grazing and confinement (12).

Qualitative responses regarding selection of breeds for their crossbreeding programs varied widely. Many producers already had mixed herds, and their breed selection was limited by the composition of the animals they already owned. Among those producers who were crossbreeding Holstein females to sires of another breed, nearly all cited a desire to reduce calving difficulties by mating their Holstein heifers to sires of a smaller breed. Most also cited a need to improve cow fertility, health, and survival through crossbreeding, and many also noted a desire to improve fat and protein percentages. A few producers wanted greater heat tolerance, a more docile temperament, improved grazing ability, increased strength, reduced body size, or less inbreeding. Conversely, many producers who began with another breed cited improved milk production as 
the reason they began crossbreeding with Holstein bulls.

These herds had been crossbreeding for $8.9 \mathrm{yr}$, on average, with 19 herds crossbreeding for fewer than 5 $\mathrm{yr}$ and 10 herds crossbreeding for more than $15 \mathrm{yr}$. Thirty-nine herds began by crossbreeding their existing cattle only, while eight crossbred their existing cattle and purchased crossbred animals. Among the initial $\left(\mathrm{F}_{1}\right)$ crossbred matings of their existing cattle, $77.4 \%$ were to AI sires and $22.6 \%$ were to natural service bulls. Twenty-one herds used AI exclusively for these initial crossbred matings, while six herds used only natural service.

Forty-one herds were currently mating their crossbred cows back to purebred bulls of (one of) the parental breeds (e.g., mating Holstein $\times$ Jersey crossbred cows to purebred Holstein or Jersey bulls). Twenty-four of these herds were using AI exclusively for these backcross matings, 14 were using a combination of $\mathrm{AI}$ and natural service, and one was using natural service only. Among herds that were using purebred AI sires, their sire selection criteria (milk, protein, longevity, fertility, udders, feet, and legs) did not appear to differ greatly from that of a typical US dairy producer. Eight herds were currently mating their crossbred cows to purebred bulls of another breed (e.g., mating Holstein $\times$ Jersey crossbred cows to purebred Brown Swiss bulls). Five of these herds were using AI exclusively, while two were using a mixture of AI and natural service, and one was using natural service only. Six herds were currently mating their crossbred cows to crossbred bulls of the same breed composition (e.g., mating Holstein $\times$ Jersey crossbred cows to Holstein $\times$ Jersey crossbred bulls). Two of these herds were using AI exclusively for these matings, and three were using only natural service. None of the herds were using crossbred bulls of a different breed composition (e.g., mating Holstein $\times$ Jersey crossbred cows to Holstein $\times$ Brown Swiss crossbred bulls). Among those herds that were not currently using crossbred bulls, nine indicated that they would consider crossbred bulls in the future, whereas 23 indicated that they would not consider using crossbred bulls.

As shown in Table 1, a wide variety of breeds and breed crosses was represented. The most common cross involved Jersey sires mated to Holstein dams; 16 herds had milking animals of this type, whereas 23 and 18 herds had heifers and pregnancies, respectively. Brown Swiss sires were also mated to Holstein dams frequently, with 13,11 , and 11 herds having milking cows, heifers, and pregnancies, respectively, of this genetic composition. Backcrosses involving Brown Swiss sires mated to $F_{1}$ Brown Swiss $\times$ Holstein cows, Jersey sires mated to $F_{1}$ Jersey $\times$ Holstein cows, and Holstein sires mated to $F_{1}$ Brown Swiss $\times$ Holstein cows were represented in roughly five to seven herds each.

Thirty-seven farms indicated participation in a supervised DHI testing program, whereas seven participated in an owner-sampler program, and three did not routinely record milk weights or components. As shown in Table 1, these producers used a variety of methods to record the ancestry of their crossbred cows within the DHI system. For example, $\mathrm{F}_{1}$ crosses of Holstein sires and Jersey dams were recorded with breed codes $\mathrm{H}$, J, or X on different farms. In backcrosses, producers tended to use the breed code of sire (e.g., Brown Swiss $\times$ [Brown Swiss $\times$ Holstein] animals were recorded as B), but some recorded these animals as $\mathrm{X}$, and a few herds even assigned the dam's breed code to $\mathrm{F}_{1}$ and/or backcross offspring. Clearly, there is a need for a more suitable system for recording the ancestry and breed composition of crossbred dairy cattle in this country.

Table 2 has producers' scores regarding the ability of cows of each breed or breed cross to fit comfortably into their existing free stalls and milking parlor. Scores regarding the cows' ability to fit into free stalls ranged from 2.72 for $\mathrm{F}_{1}$ Jersey $\times$ Holstein cows to 3.32 for pure Holstein cows. Scores regarding the cows' ability to fit into the milking parlor ranged from 2.18 for pure Jerseys to 3.39 for pure Holsteins. Crosses involving Holsteins and Brown Swiss received scores similar to those of pure Holsteins, whereas scores for $\mathrm{F}_{1}$ Jersey $\times$ Holstein cows were very close to the average of the two parental breeds. Expected size of the crossbred animals is a common concern among producers, particularly those who have recently expanded or remodeled their facilities.

Table 3 shows producers' scores for milk volume, component percentages, and involuntary culling rate. Average scores for milk volume ranged from 2.00 for pure Jersey cows to 3.79 for pure Holstein cows. Scores for pure Brown Swiss cows (2.40) were similar to those of $\mathrm{F}_{1}$ Jersey $\times$ Holstein cows (2.52), whereas scores for $\mathrm{F}_{1}$ Brown Swiss $\times$ Holstein cows (2.90) were similar to those of backcross Holstein $\times$ (Holstein $\times$ Jersey) cows (3.00). Conversely, component percentages were highest for pure Jersey cows (4.55), followed by $\mathrm{F}_{1}$ Jersey $\times$ Holstein cows (3.88), and $\mathrm{F}_{1}$ Brown Swiss $\times$ Holstein cows (3.65). All breed combinations scored substantially higher than pure Holsteins (2.29). Although we did not specifically ask about fat content vs. protein content, several producers voluntarily noted that the superiority of their crossbred animals, relative to their pure Holsteins, was much greater for fat percentage than for protein percentage. Scores for involuntary culling rate (i.e., culling for reasons other than low milk production) were lowest for $\mathrm{F}_{1}$ Jersey $\times$ Holstein cows (2.42), indicating that these animals were significantly less likely to 
Table 1. Number of herds $\left(\mathrm{N}_{\mathrm{H}}\right)$ and animals $\left(\mathrm{N}_{\mathrm{A}}\right)$ from each breed or breed cross represented by participants in the survey, as well as the breed codes(s) currently assigned to each breed or breed cross within the DHI milk recording system.

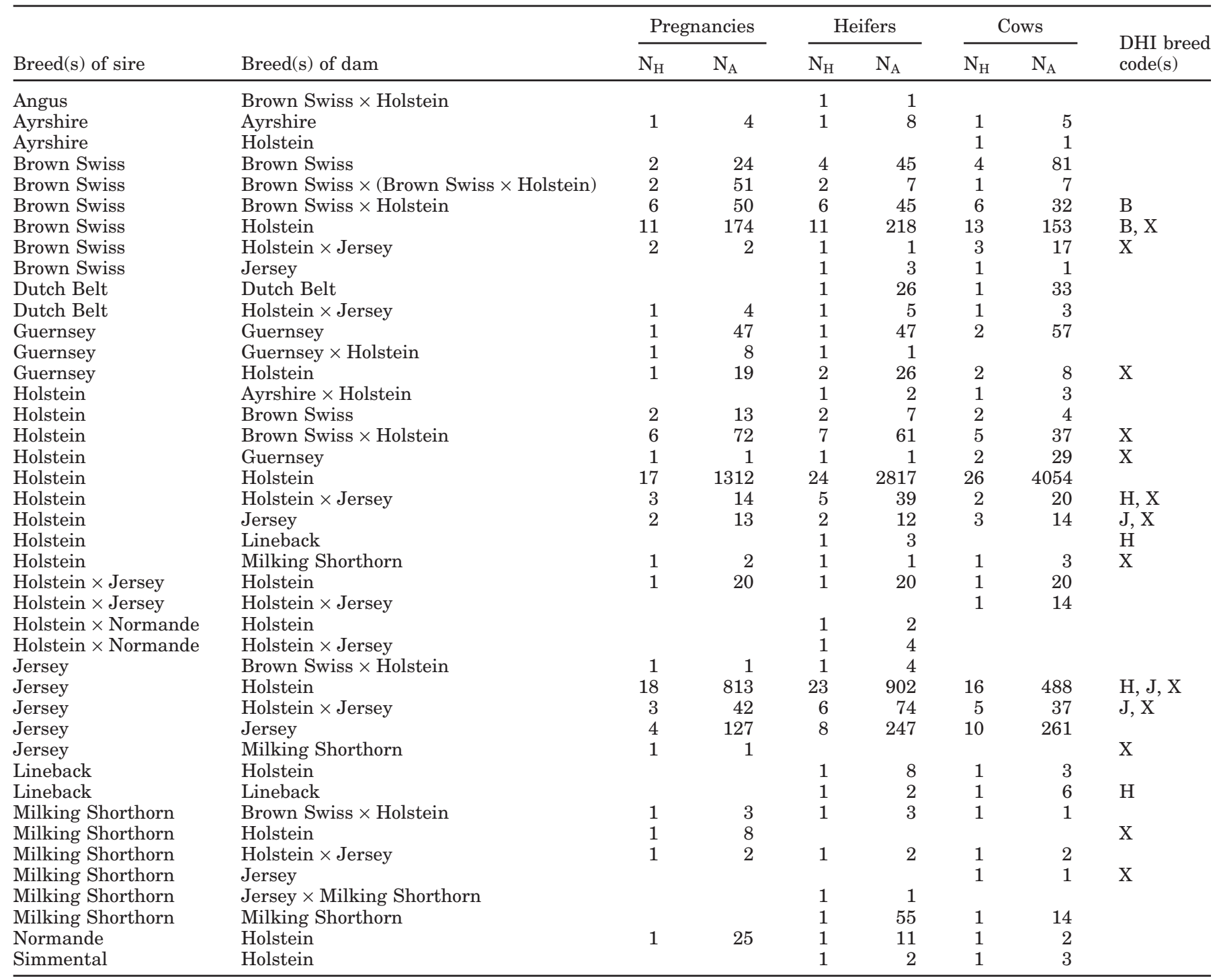

${ }^{1}$ Typical DHI breed codes are: B = Brown Swiss, $\mathrm{H}=$ Holstein, $\mathrm{J}=$ Jersey, and $\mathrm{X}=$ cross bred.

Table 2. Producer scores regarding the ability of cows from each breed or breed cross to fit into the freestalls and the milking parlor.

\begin{tabular}{|c|c|c|c|c|c|}
\hline \multirow[b]{2}{*}{$\operatorname{Breed}(\mathrm{s})$ of sire } & \multirow[b]{2}{*}{ Breed(s) of dam } & \multicolumn{2}{|c|}{ Ability to fit the freestalls ${ }^{1}$} & \multicolumn{2}{|c|}{$\begin{array}{l}\text { Ability to fit the } \\
\text { milking parlor }\end{array}$} \\
\hline & & No.of herds & Mean & No. of herds & Mean \\
\hline Brown Swiss & Holstein & 7 & $3.07 \pm 0.18$ & 10 & $3.25 \pm 0.1$ \\
\hline Holstein & Holstein & 17 & $3.32 \pm 0.11$ & 23 & $3.39 \pm 0.10$ \\
\hline Jersey & Holstein & 9 & $2.72 \pm 0.16$ & 15 & $2.73 \pm 0.13$ \\
\hline Jersey & Jersey & & & 7 & $2.18 \pm 0.19$ \\
\hline
\end{tabular}

${ }^{1}$ Scoring system: 1 = cows are much too small; $2=$ cows are slightly too small; $3=$ cows are about the right size; $4=$ cows are slightly too big; $5=$ cows are much too big. 
Table 3. Producer scores regarding milk volume, component (fat and protein) percentages, and involuntary culling rate for cows from each breed or breed cross.

\begin{tabular}{|c|c|c|c|c|c|c|c|}
\hline \multirow[b]{2}{*}{ Breed(s) of sire } & \multirow[b]{2}{*}{ Breed(s) of dam } & \multicolumn{2}{|c|}{ Milk volume $^{1}$} & \multicolumn{2}{|c|}{$\begin{array}{l}\text { Component } \\
\text { percentages }^{2}\end{array}$} & \multicolumn{2}{|c|}{ Involuntary culling ${ }^{3}$} \\
\hline & & No. of herds & Mean & No. of herds & Mean & No of herds & Mean \\
\hline Brown Swiss & Holstein & 11 & $2.90 \pm 0.24$ & 10 & $3.65 \pm 0.25$ & 9 & $2.88 \pm 0.27$ \\
\hline Holstein & Holstein & 29 & $3.79 \pm 0.15$ & 24 & $2.29 \pm 0.16$ & 19 & $3.42 \pm 0.18$ \\
\hline Holstein & Holstein $\times$ Jersey & 5 & $3.00 \pm 0.36$ & & & & \\
\hline Jersey & Holstein & 21 & $2.52 \pm 0.17$ & 17 & $3.88 \pm 0.19$ & 14 & $2.42 \pm 0.21$ \\
\hline
\end{tabular}

${ }^{1}$ Scoring system: 1 = milk production is much lower; $2=$ milk production is slightly lower; $3=$ milk production is about the same; $4=$ milk production is slightly higher; $5=$ milk production is much higher.

${ }^{2}$ Scoring system: 1 = fat and protein percentages are much lower; 2 = fat and protein percentages are slightly lower; $3=$ fat and protein percentages are about the same; $4=$ fat and protein percentages are slightly higher; $5=$ fat and protein percentages are much higher.

${ }^{3}$ Scoring system: 1 = involuntary culling rate is much lower; $2=$ involuntary culling rate is slightly lower; $3=$ involuntary culling rate is about the same; $4=$ involuntary culling rate is slightly higher; $5=$ involuntary culling rate is much higher.

leave the herd early in life due to illness, injury, or infertility than pure Jersey cows (2.66) or $\mathrm{F}_{1}$ Brown Swiss $\times$ Holstein cows (2.88). Producer scores were highest for pure Holstein cows (3.42), indicating a significantly higher rate of culling for these animals than any other breed or cross. Based on these data, it appears that crossbreeding with Brown Swiss or, particularly, Jerseys can provide significant improvement in dairy cow longevity.

Cow fertility is an important component of longevity, because infertility is presently the most common reason for culling in most dairy herds. Producers' scores for conception rates of milking cows and virgin heifers are shown in Table 4. Among milking cows, conception rate scores were highest for matings involving Jersey sires that were mated to $\mathrm{F}_{1}$ Holstein $\times$ Jersey cows (3.66) or to pure Jersey cows (3.60). Conception rate scores for matings involving pure Holstein cows and either Brown Swiss (3.45) or Jersey (3.30) sires were also significantly higher than scores for pure Holstein (2.73) or pure Brown Swiss (2.40) matings. Thus, it appears that crossbreeding programs involving Holstein cows and either Brown Swiss or Jersey sires may achieve concep- tion rates similar to those currently observed in purebred Jersey matings. Although conception rates in virgin heifers are rarely considered a problem, scores for matings involving virgin Holstein heifers and either Brown Swiss (3.55) or Jersey sires (3.46) were slightly higher than scores for pure Jersey matings (3.28), and significantly higher than scores for pure Holstein (3.00) or Brown Swiss matings (2.33).

It is relatively common for producers to seek a reduction in calving problems by mating Holstein heifers to bulls of another breed, particularly Jerseys, and producers' scores for calving difficulty and calf mortality of each breed or breed cross are shown in Table 5. As expected, calving problems were least common in matings involving Jersey sires and either Holstein heifers (1.54), Jersey heifers (1.54), or $F_{1}$ Holstein $\times$ Jersey crossbred heifers (1.67). Scores for pure Brown Swiss matings (2.44) were significantly lower than scores for crossbred matings involving Brown Swiss sires and Holstein heifers (3.38). Interestingly, scores for matings involving Holstein sires and $\mathrm{F}_{1}$ Holstein $\times$ Jersey crossbred heifers (3.04) were significantly lower than scores for purebred Holstein matings (3.88), despite the

Table 4. Producer scores regarding conception rate for matings involving milking cows, virgin heifers, and service sires from each breed or breed cross.

\begin{tabular}{lllllll}
\hline & & \multicolumn{2}{c}{ Cow conception rate $^{1}$} & & \multicolumn{2}{c}{ Heifer conception rate $^{1}$} \\
Breed(s) of service sire & Breed(s) of females & No. of herds & Mean & & No. of herds & Mean \\
\hline Brown Swiss & Brown Swiss & 5 & $2.40 \pm 0.39$ & & 6 & $2.33 \pm 0.22$ \\
Brown Swiss & Holstein & 10 & $3.45 \pm 0.28$ & 9 & $3.55 \pm 0.18$ \\
Holstein & Holstein & 19 & $2.73 \pm 0.20$ & 16 & $3.00 \pm 0.13$ \\
Jersey & Holstein & 20 & $3.30 \pm 0.19$ & & 15 & $3.46 \pm 0.14$ \\
Jersey & Holstein $\times$ Jersey & 6 & $3.66 \pm 0.36$ & & \\
Jersey & Jersey & 5 & $3.60 \pm 0.39$ & 7 & $3.28 \pm 0.21$ \\
\hline
\end{tabular}

${ }^{1}$ Scoring system: 1 = conception rate is much lower; $2=$ conception rate is slightly lower; $3=$ conception rate is about the same; $4=$ conception rate is slightly higher; 5 = conception rate is much higher. 
Table 5. Producer scores regarding calving ease for matings involving virgin heifers and service sires from each breed or breed cross, as well as calf survival for calves from milking cows or virgin heifers and service sires from each breed or breed cross.

\begin{tabular}{|c|c|c|c|c|c|}
\hline \multirow[b]{2}{*}{ Breed(s) of service sire } & \multirow[b]{2}{*}{ Breed(s) of females } & \multicolumn{2}{|c|}{ Calving difficulty $^{1}$} & \multicolumn{2}{|c|}{ Calf mortality $^{2}$} \\
\hline & & No. of herds & Mean & No. of herds & Mean \\
\hline Brown Swiss & Brown Swiss & 5 & $2.44 \pm 0.34$ & & \\
\hline Brown Swiss & Holstein & 12 & $3.38 \pm 0.22$ & 10 & $2.51 \pm 0.25$ \\
\hline Holstein & Holstein & 25 & $3.88 \pm 0.15$ & 19 & $2.57 \pm 0.18$ \\
\hline Holstein & Holstein $\times$ Jersey & 7 & $3.04 \pm 0.28$ & 5 & $2.31 \pm 0.36$ \\
\hline Holstein & Jersey & & & 5 & $1.91 \pm 0.36$ \\
\hline Jersey & Holstein & 23 & $1.54 \pm 0.15$ & 22 & $2.31 \pm 0.17$ \\
\hline Jersey & Holstein $\times$ Jersey & 8 & $1.67 \pm 0.26$ & 6 & $2.68 \pm 0.33$ \\
\hline Jersey & Jersey & 8 & $1.54 \pm 0.26$ & 9 & $3.17 \pm 0.27$ \\
\hline
\end{tabular}

\footnotetext{
${ }^{1}$ Scoring system: 1 = much less calving difficulty; 2 = slightly less calving difficulty; 3 = about the same calving difficulty; 4 = slightly more calving difficulty; $5=$ much more calving difficulty.

${ }^{2}$ Scoring system: 1 = mortality rate is much lower; 2 = mortality rate is slightly lower; 3 = mortality rate is about the same; $4=$ mortality rate is slightly higher; $5=$ mortality rate is much higher.
}

smaller size of the crossbred heifers. Thus, it appears that a significant, undesirable maternal effect for calving difficulty exists within the Holstein breed.

Producers' scores for calf mortality are also shown in Table 5. Scores were lowest for $\mathrm{F}_{1}$ Holstein $\times$ Jersey calves (1.91), $\mathrm{F}_{1}$ Jersey $\times$ Holstein calves, and backcross Holstein $\times($ Holstein $\times$ Jersey) calves (2.31), indicating a higher survival rate among these crossbred calves. Scores for $\mathrm{F}_{1}$ Brown Swiss $\times$ Holstein calves (2.51) and pure Holstein calves (2.57) were higher than those of the aforementioned crosses. However, both were slightly lower than scores for backcross Jersey $\times($ Holstein $\times$ Jersey) calves (2.68) and significantly lower than scores for pure Jersey calves (3.17). The latter result seems to indicate an undesirable direct effect on survival for calves with a high percentage of Jersey genes. However, a comparison of scores for calves with Holstein sires and either Jersey, $\mathrm{F}_{1}$ Holstein $\times$ Jersey, or Holstein dams (1.91, 2.31, and 2.57, respectively) seem to also indicate a beneficial maternal effect on survival for calves from dams with a higher percentage of Jersey genes.

A common concern among producers who are considering crossbreeding is the potential loss of revenue associated with depressed prices for crossbred animals sold as breeding stock or, particularly, for slaughter. Table 6 shows producers' scores for prices of cows that were

Table 6. Producer scores regarding sale prices for cows from each breed or breed cross that were sold for dairy purposes.

\begin{tabular}{llll}
\hline & & \multicolumn{2}{c}{ Cows sold for dairy ${ }^{1}$} \\
\cline { 3 - 4 } Breed(s) of sire & Breed(s) of dam & No. of herds & Mean \\
\hline Holstein & Holstein & 7 & $4.14 \pm 0.43$ \\
Jersey & Holstein & 8 & $2.62 \pm 0.40$ \\
\hline
\end{tabular}

${ }^{1}$ Scoring system: $1=$ sale price is much lower; $2=$ sale price is slightly lower; $3=$ sale price is about the same; $4=$ sale price is slightly higher; $5=$ sale price is much higher. sold for dairy purposes. Although the number of herds that responded to these questions was quite limited (as is the number of females sold by these herds each year), one can see that pure Holstein cows (4.14) tend to command higher prices than $\mathrm{F}_{1}$ Jersey $\times$ Holstein cows (2.62) when sold for dairy purposes.

Data regarding the cull cows, market steers, and bull calves that were sold for slaughter purposes are shown in Table 7. Market prices for $\mathrm{F}_{1}$ Brown Swiss $\times$ Holstein cull cows (3.40) and pure Holstein cull cows (3.22) were significantly higher than prices for $\mathrm{F}_{1}$ Jersey $\times$ Holstein cull cows (2.47). Pure Holstein steers (3.20) received significantly higher scores for market prices than $\mathrm{F}_{1}$ Jersey $\times$ Holstein steers (2.62). Pure Holstein bull calves (3.47) and $\mathrm{F}_{1}$ Brown Swiss $\times$ Holstein bull calves (3.10) received significantly higher prices than backcross Holstein $\times\left(\right.$ Holstein $\times$ Jersey) calves $(2.21), \mathrm{F}_{1}$ Jersey $\times$ Holstein calves (1.95), backcross Jersey $\times($ Holstein $\times$ Jersey) calves (2.00), or pure Jersey calves (1.50). Thus, it appears that low prices for bull calves, market steers, and cull cows for crosses involving the Jersey breed are a legitimate concern.

Regarding future plans, producers of 40 herds indicated their intent to continue crossbreeding in the future, six planned to discontinue crossbreeding, and four failed to disclose their plans. When producers were asked to list the main advantages of crossbreeding, the overwhelming responses were calving ease, fertility, component percentages, longevity, and calf vitality. A few herds indicated improvement in feet and legs, temperament, grazing performance, (increased or decreased) body size, less inbreeding, and milk production (herds converting to Holstein from another breed). When asked to list the main disadvantages, the most common responses were: marketability of slaughter animals and bull calves, lack of uniformity in the herd, difficulty in choosing mates for the next generation, and reduced milk volume. 
Table 7. Producer scores regarding sale prices for cull cows, market steers, and bull calves from each breed or breed cross that were sold for slaughter purposes.

\begin{tabular}{|c|c|c|c|c|c|c|c|}
\hline \multirow[b]{2}{*}{ Breed(s) of sire } & \multirow[b]{2}{*}{$\operatorname{Breed}(\mathrm{s})$ of dam } & \multicolumn{2}{|c|}{ Cull cow price ${ }^{1}$} & \multicolumn{2}{|c|}{ Market steer price $^{1}$} & \multicolumn{2}{|c|}{ Bull calf price ${ }^{1}$} \\
\hline & & No. of herds & Mean & No. of herds & Mean & No. of herds & Mean \\
\hline Brown Swiss & Holstein & 10 & $3.40 \pm 0.23$ & & & 10 & $3.10 \pm 0.29$ \\
\hline Holstein & Holstein $\times$ Jersey & & & & & 7 & $2.21 \pm 0.34$ \\
\hline Jersey & Holstein & 17 & $2.47 \pm 0.17$ & 8 & $2.62 \pm 0.32$ & 22 & $1.95 \pm 0.19$ \\
\hline Jersey & Holstein $\times$ Jersey & & & & & 6 & $2.00 \pm 0.37$ \\
\hline Jersey & Jersey & & & & & 8 & $1.50 \pm 0.32$ \\
\hline
\end{tabular}

${ }^{1}$ Scoring system: $1=$ sale price is much lower; $2=$ sale price is slightly lower; $3=$ sale price is about the same; $4=$ sale price is slightly higher; $5=$ sale price is much higher.

\section{CONCLUSIONS}

Based on the results of this survey, it appears that crossbreeding can play a role in improving the profitability and longevity of US dairy cattle. Nearly all producers who responded to this survey cited improvements in fertility, calving ease, and milk composition. The advantage in milk volume of the Holstein breed remains, but changes in milk pricing, coupled with declining fertility and high replacement prices, may make crossbreeding appealing to a broader group of commercial producers in the future. Marketing of crossbred animals remains difficult, and the lack of uniformity within the milking herd can create management challenges. Producers who responded to this study tended to make heavy use of purebred AI sires for the $\mathrm{F}_{1}$ and backcross matings, but some were indecisive about plans for subsequent generations, and interest in crossbred bulls was limited. The present study provides an overview of producers' experiences with crossbreeding in this country, and it provides topics for additional, more detailed research regarding specific traits and/or specific breed crosses. Future research should focus on estimation of heterosis for component percentages and functional traits (not just milk yield) for each of the most common breed crosses. Subsequently, plans to exploit this heterosis, as well as the particular advantages of each breed (i.e., breed complementarity) in first and later generation crosses should be developed.

\section{REFERENCES}

Ahlborn-Breier, G., and W. D. Hohenboken. 1991. Additive and nonadditive genetic effects for milk production in dairy cattle: Evidence for major individual heterosis. J. Dairy Sci. 74:592-602.

Lopes-Villalobos, N., D. J. Garrick, C. W. Holmes, H. T. Blair, and R. D. Spelman. 2000. Profitabilities of some matings systems for dairy herds in New Zealand. J. Dairy Sci. 83:144-153.

McAllister, A. J. 2002. Is crossbreeding the answer to questions of dairy breed utilization? J. Dairy Sci. 85:2352-2357.

McAllister, A. J., A. J. Lee, T. R. Batra, C. Y. Lin, G. L. Roy, J. A. Vesely, J. M. Wauthy, and K. A. Winter. 1994. The influence of additive and non-additive gene action on lifetime yields and profitability in dairy cattle. J. Dairy Sci. 77:2400-2414.

Swan, A. A., and B. P. Kinghorn. 1992. Evaluation and exploitation of crossbreeding in dairy cattle. J. Dairy Sci. 75:624-639.

Touchberry, R. W. 1992. Crossbreeding effects in dairy cattle: The Illinois experiment, 1949 to 1969. J. Dairy Sci. 75:640-667.

VanRaden, P. M., and A. H. Sanders. 2001. Economic merit of purebred and crossbred dairy cattle. J. Dairy Sci. Online Proc. ADSA Annual Mtg., Indianapolis, IN. http://www.fass.org/fass01/pdfs/ VanRaden.pdf. 